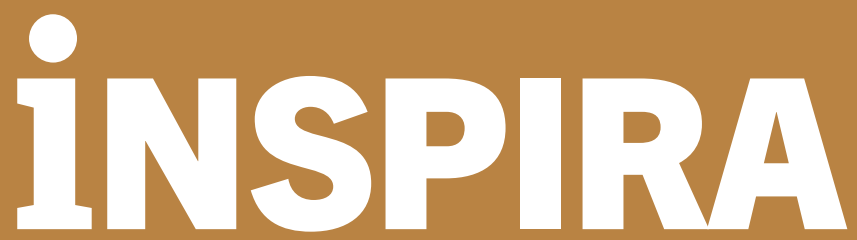

Tidsskrift for anestesi-, operasjon- og intensivsykepleiere

Forskningsartikler | Vol. 16, No. 1, 2021, s. 30-46

\title{
Intensivsykepleieres opplevelser med langtids-intensivpasienters indre styrke og vilje til overlevelse
}

\author{
Tove Engan Paulsby \\ Intensivsykepleier, universitetslektor/førstelektorkandidat, Institutt for samfunnsmedisin og sykepleie, Fakultet for medisin \\ og helsevitenskap, NTNU, Norge \\ E-post: tove.e.paulsby@ntnu.no

\section{Ingeborg Alexandersen} \\ Intensivsykepleier, førstelektor, Institutt for samfunnsmedisin og sykepleie, Fakultet for medisin og helsevitenskap, \\ NTNU, Norge
}

\section{Stine Borgen Lund}

Intensivsykepleier, universitetslektor/ph.d.-student, Institutt for samfunnsmedisin og sykepleie, Fakultet for medisin og helsevitenskap, NTNU, Norge

\section{Gørill Haugan ${ }^{1,2}$}

${ }^{1}$ Sykepleier, professor, Institutt for samfunnsmedisin og sykepleie, Fakultet for medisin og helsevitenskap, NTNU, Norge ${ }^{2}$ Sykepleier, professor, Fakultet for sykepleie og helsevitenskap, Nord universitet, Norge

\section{Sammendrag}

Bakgrunn: Indre styrke og viljekraft anses som essensielle salutogene ressurser for tilfriskning og overlevelse blant langtids-intensivpasienter. Hvordan disse ressursene fremmes av intensivsykepleierne er mindre kjent.

Hensikt: Studiens hensikt var å få kunnskap om hvilke opplevelser intensivsykepleierere har med langtids-intensivpasienters indre styrke og vilje til overlevelse.

Metode: Kvalitative data ble samlet inn ved tre fokusgruppediskusjoner med ti erfarne intensivsykepleiere ved tre ulike sykehus i Norge. Datamaterialet ble analysert ved hjelp av systematisk tekstkondensering.

Resultat: I den akutte og kritiske fasen av intensivoppholdet, opplevde intensivsykepleierne pasientens overlevelse som nært knyttet til behandling og underst $\varnothing t t e$ av medisinskteknisk utstyr. I den mer stabile fasen kunne de fortelle om opplevelser knyttet til pasientens vilje på et konkret og et mer abstrakt plan. Viljen til å komme hjem var en sterk kraft som intensivsykepleierne underst $\varnothing t t e t$. De opplevde pårørende som en viktig helsefremmende ressurs, og la tilrette for deres

\footnotetext{
(c) 2021 Tove Engan Paulsby, Ingeborg Alexandersen, Stine Borgen Lund \& Gørill Haugan. This is an Open Access article distributed under the terms of the Creative Commons Attribution 4.0 International License (http://creativecommons.org/licenses/by/4.0/). 
tilstedeværelse. Intensivsykepleierne fortalte også om ulike handlinger som kan være viktige for å fremme langtids-intensivpasienters helsefremmende ressurser. Se nytt innhold for resultatet skrevet inn ovenfor.

Konklusjon: Studien viser at intensivsykepleiere synes mindre oppmerksomme overfor langtidsintensivpasienters indre styrke og vilje til overlevelse i den akutte og kritiske fasen. Oppmerksomheten aktualiseres i hovedsak når pasientene er mer stabile og mindre sedert. Intensivsykepleierne demonstrer en intuitiv forståelse for pasienters indre styrke som salutogen ressurs og hvordan den kan fremmes. Denne intuitive kunnskapen b $\varnothing$ r videreutvikles og integreres ytterligere i praksisfeltet og i utdanningen av intensivsykepleiere.

Nøkkelord: helsefremming; indre styrke; kvalitativ forskning; langtids-intensivpasienter; salutogen intensivsykepleie; vilje til overlevelse

\section{Abstract}

\section{Intensive care nurses' experiences of long-term critically ill patients' inner strength and will to survive}

Background: Inner strength and willpower are deemed essential salutogenic resources for recovery and survival among long-term critically ill patients. However, less is known of how these resources are promoted by health professionals.

Aim: This study aims to provide knowledge of how intensive care unit (ICU) nurses experiences of long-term critically ill patients' inner strength and will to survive.

Methods: Qualitative data were collected by means of three focus group discussions involving ten experienced ICU nurses in three Norwegian hospitals. The data were analyzed by means of systematic text condensation.

Results: In the acute, critical part of the ICU-trajectory, the ICU nurses experienced survival closely related to treatment and the medical technical support. When stable and awake, the patients expressed will to survive both concretely and abstractly. The patients' goal of coming home was a boosting power supported by the nurses. Family support was vital, and the nurses facilitated their presence. The ICU nurses demonstrated a variety of professional actions of significance in promoting long-term critically ill patients' salutogenic resources.

Conclusion: This study indicate that ICU nurses are less attentive towards long-term critically ill patients' inner strength and will to survive in the acute and critical phase. The attention is more present when the patients are more awake and less sedated. The ICU nurses expose intuitive understanding of patients' inner strength and will to survive as well as how to promote these salutogenic resources. This intuitive knowledge should be further developed and integrated in clinical practice and educational settings.

Keywords: health promotion; inner strength; long-term critically ill patients; qualitative study; salutogenic ICU nursing; willpower

\section{Introduksjon}

Ifølge Norsk intensivregister behandles ca. 15000 pasienter ved norske intensivavdelinger hvert år: blant disse overlever ca. 90 \% oppholdet og ca. 80 \% er i live 30 dager etter innleggelse $(1,2)$. Som i andre deler av helsetjenesten har det vært en rivende utvikling og endringer i måten intensivsykepleie utøves, blant annet er innføring av protokoller for vurdering av smerter og sedasjonsnivå særlig aktuelt med tanke på ønsket om mer våkne pasienter (3). Til tross for stor innsats fra helsepersonellet i intensivavdelinger 
innebærer prosessen mot overlevelse av alvorlig sykdom/skade både lidelse og store plager $(4,5)$. Nevromuskulær svikt, redusert hukommelse, depresjoner og angst er eksempler på symptomer som ses ved post-intensive care syndrome (PICS) (6).

I intensivavdelingen er det et naturlig fokus på patogenesen (sykdom og risiko for sykdom), mens salutogenesen og helsefremming har generelt hatt mindre fokus. I 2017 ble det helsefremmende perspektivet en del av funksjons- og ansvarsbeskrivelsen for intensivsykepleie (7). Den salutogene helseforståelsen er holistisk og basert i en forståelse av mennesket som en enhet hvor fysisk-psykologisk-sosial-åndelig-eksistensielle aspekter er integrert og interagerer med hverandre (8). Intensivpasientens overlevelse og velvære bør forstås i lys av mer enn bare den fysiske overlevelsen, og den helhetlige helseforståelsen bør løftes ytterligere fram og bevisstgjøres for å fremme intensivpasientens tilfriskningsprosess. Derfor utforsker denne studien intensivsykepleiernes opplevelser av helsefremmende sykepleie.

Aron Antonovsky utviklet den salutogene helseforståelsen som innebærer at ingen er absolutt friske (ease) eller syke (dis-ease), men til enhver tid befinner seg på et kontinuum mellom ease og dis-ease (9), alltid med en grad av helse. Han hevdet at under store påkjenninger og alvorlige livshendelser finnes det ressurser i mennesket og dets omgivelser som påvirker helsen positivt (9). Begrepene «opplevelse av sammenheng» (OAS) og «generelle motstandsressurser» (GMR) er sentrale i den salutogene helseforståelsen. OAS beskrives som en grunnleggende holdning til hvordan stimuli fra omgivelser i livet erfares, mens GMR forstås som egenskaper ved personen selv, gruppen eller omgivelsene som bidrar til mestring (9). En sterk OAS innebærer at individet opplever sitt liv som begripelig, håndterbart og meningsfullt (10). Alvorlig syke pasienter som skårer høyt på OAS mestrer sin sykdomssituasjon bedre. Wåhlin og kolleger fremhever intensivpasienters livsmot, indre styrke, OAS, mestring og vilje til overlevelse som sentrale ressurser for tilfriskning (11). Drageset, Ellingsen og Haugan drøfter hvordan helsepersonell i sykehus kan bidra til å fremme pasienters helse og mestring gjennom å prioritere oppmerksomheten mot pasientenes egne opplevelser og ressurser (12). Figur 1 viser hvordan de salutogene begrepene OAS og GMR, samt viljestyrke, indre styrke og vilje til overlevelse teoretisk henger sammen. Figuren demonstrerer helsekontinuumet mellom ease $(\mathrm{H}+)$ og dis-ease (H-): alvorlig sykdom/skade oppstår, og intensivpasienten befinner seg et sted «mellom liv og død»; utfallet er usikkert. Videre skisserer figur 1 hvordan smerter, lidelse og plager kan utmatte pasientens indre GMR, som her er representert ved livsmot, indre styrke, viljestyrke / vilje til overlevelse, samt pasientens nære familie og intensivsykepleierne. Disse anses som salutogene ressurser som bidrar til å bevege pasienten mot kontinuumets høyre side, dvs. helse (H+).

Et intensivopphold skyldes oftest alvorlig skade eller sykdom og representerer store belastninger som smerter, mareritt eller andre plager som medfører fysisk og psykisk kraftløshet: å gjennomleve store smerter og plager er krevende og bidrar over tid til å svekke pasientens indre styrke og livsmot. Dersom livsmotet svekkes, har pasienten ifølge Antonovsky (9) mindre tilgang til sine iboende helsefremmende ressurser, slik 


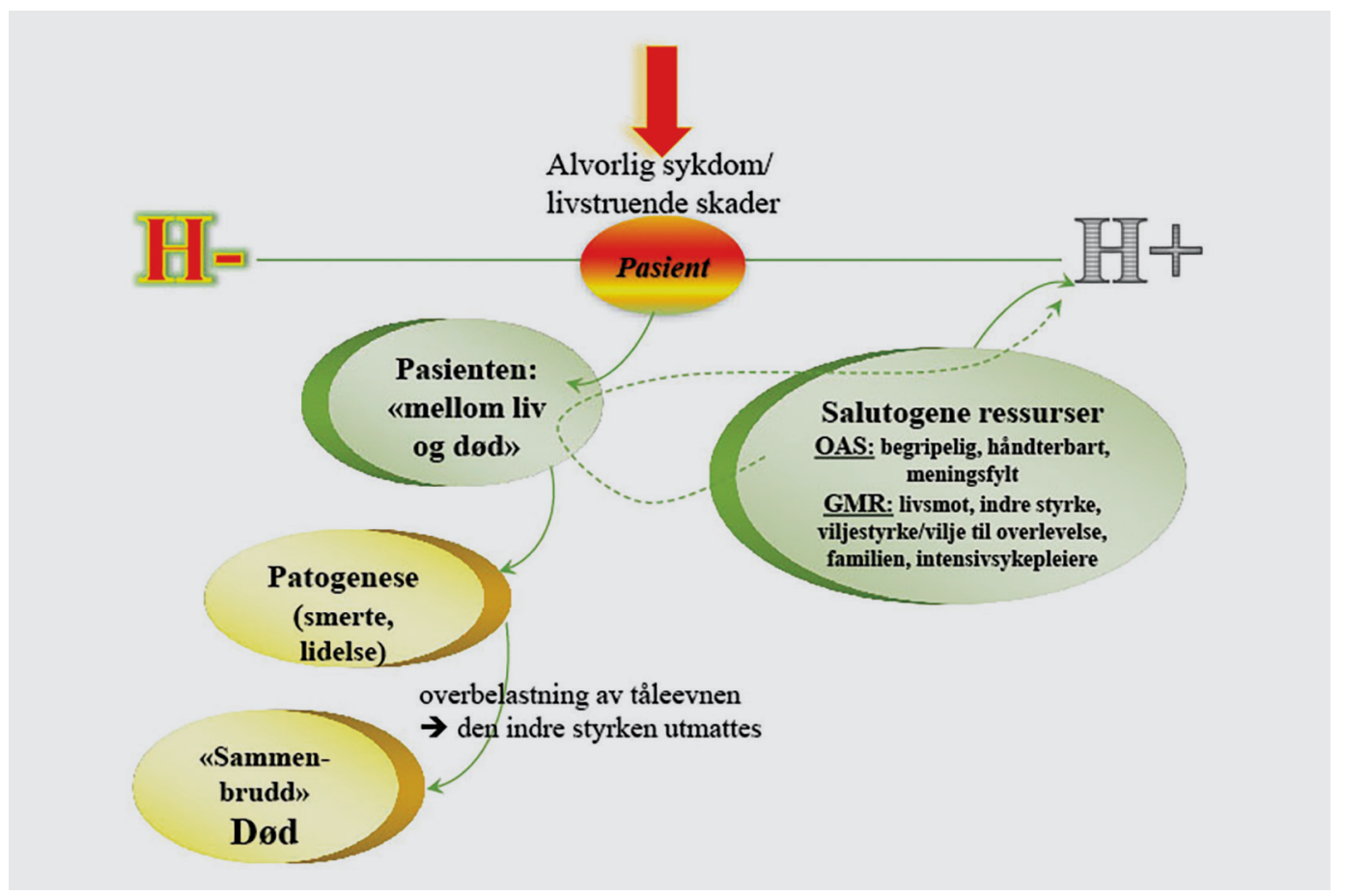

Figur 1: Sammenhengen mellom begrepene salutogenese, OAS, GMR, livsmot, indre styrke og viljestyrke/vilje til overlevelse. (c) Gørill Haugan

som OAS og GMR. Ifølge Kari Martinsen kan pasientens livsmot, vilje og styrke til å leve livet og bearbeide lidelsen påvirke de iboende helsefremmende prosessene (13). Videre kan opplevelsen av stor avhengighet av andre medføre at mange intensivpasienter resignerer, gir opp og ser døden som det enkleste alternativet (11). I denne studien forstås indre styrke som et indre, personlig og relasjonelt fenomen som representerer en helsefremmende ressurs for intensivpasienters reise gjennom intensivoppholdets utfordringer (14). Indre styrke kan også forstås som et aspekt ved pasientens GMR; en ressurs som bidrar til mestring, helse og overlevelse (9).

Henden (15) forstår viljestyrke (willpower) som en kilde til motivasjon for å opprettholde selvkontroll, liv, helse og velvære. Viljestyrke representerer en indre personlig kraft som individet anvender for å holde livsmotet oppe, holde ut, tåle, samt å nå sine mål. Ifølge Karp og kollegaer kan denne viljen trenes (16), men for mange intensivpasienter er påkjenningene både fysisk, mentalt og eksistensielt svært store. I noen tilfeller så store at pasienten synes å ville gi opp, det vil si at viljestyrken utmattes. Ofte ses en sammenheng mellom hvor sterke plager pasienten gjennomlever og lengden på intensivoppholdet; jo sterkere plager, jo lengre opphold (17), og dermed utfordres viljen ytterligere. En overbelastning av tåleevnen, og derved viljen, gir derfor risiko for at pasienter utvikler utmattelse og forfall i stedet for tilfriskning, helse og livskvalitet $(14,15)$.

En nylig studie av Alexandersen og kolleger viser at intensivsykepleierne kan være en ressurs for å fremme pasienters indre styrke og vilje til overlevelse i møte med alvorlig sykdom, lidelse og belastning (18). Følgelig kan intensivsykepleie forstås som et avgjørende aspekt ved pasientens GMR ved at intensivsykepleierne aktivt bidrar til 
at pårørende kan være til stede, samt være viktige ressurser for å bekrefte pasientens identitet og fremme viljen til overlevelse og tilfriskning. Tidligere forskning viser at langtids-intensivpasienters indre styrke er nært relatert til støtte fra familien og god intensivsykepleie (11,19-21). Dog diskuteres fremdeles nytten av familiens tilstedeværelse opp mot ulempene (22). Wåhlin og kolleger avdekket et gap mellom hva langtidsintensivpasientene $\varnothing$ nsket, og den hjelpen de fikk under intensivoppholdet i forhold til indre styrke og viljen til å kjempe (11). Alexandersen og kolleger har nylig vist at langtidsintensivpasienter opplever forhold som både fremmer og hemmer deres indre styrke og vilje til overlevelse (18). Forskning innen dette tema er ikke konkluderende, og fremdeles har vi lite kunnskap om hvordan intensivsykepleierne opplever pasienters indre styrke og vilje til overlevelse, samt hvordan de eventuelt arbeider for å fremme denne ressursen.

\section{Hensikt}

Denne studiens hensikt er å få kunnskap om hvilke opplevelser intensivsykepleiere har med langtids-intensivpasienters indre styrke og vilje til overlevelse.

\section{Metode}

Studien unders $\varnothing$ ker intensivsykepleieres opplevelser av fenomenet indre styrke og vilje til overlevelse blant langtids-intensivpasienter. I et kvalitativt design ble data samlet inn ved hjelp av fokusgruppediskusjoner. En diskusjon i en gruppe av flere intensivsykepleiere vil frembringe andre data enn individuelle intervju med den enkelte intensivsykepleier. I en diskusjon skapes data ved at gruppemedlemmene inspireres, utfordres og får nye ideer; slik kan en utvidet forståelse av fenomenet oppstå (23).

\section{Utvalg}

Avdelingsledelsen ved tre ulike intensivavdelinger ved tre ulike sykehus i Norge (1 universitetssykehus og 2 lokalsykehus) ble kontaktet. Basert i inklusjonskriteriene fant avdelingslederne mulige informanter og gav muntlig og skriftlig informasjon om studien og hva deltakelse innebar. Inklusjonskriteriene var 1) minimum fem års erfaring med langtids-intensivpasienter og 2) ansatt som sykepleier ved intensivavdelingen i 75-100\% stilling. Totalt tolv samtykket til å delta; to av disse trakk seg, dermed bestod de tre fokusgruppene av tre, tre og fire informanter.

\section{Datainnsamling}

Fokusgruppediskusjonene varte i ca. en time og ble gjennomført på informantenes arbeidssted innenfor deres arbeidstid høsten 2016. Intervjuguiden representerte en åpen tilnærming med få hovedspørsmål (tabell 1). Moderator fasiliterte en åpen og fri dialog slik at informantenes perspektiver fritt kunne komme frem (24). To av forfatterne deltok i hvert intervju. I starten presenterte moderator kort prosjektets problemstilling og gjennomføringen av intervjuet. Man etterstrebet at alle informantene deltok i 
diskusjonen: samhandlingen var god og informantene supplerte hverandre med opplevelser og konkrete fortellinger om tema, noe Malterud fremhever som metodens fortrinn (25). Samhandlingen ble benyttet til å belyse kompleksiteten i de ulike situasjonene med langtids-intensivpasienter og intensivsykepleiernes opplevelser av dem (26). Fokusgruppediskusjonene ble registrert på lydfil.

Tabell 1: Intervjuguide

Kan dere fortelle om pasienter dere har hatt ansvar for på intensivavdelingen og som dere har sett kjempe for sin overlevelse?

Hvilke faktorer opplevde dere som fremmende/betydningsfulle for pasienters vilje til å kjempe for å overleve i perioden han/hun fikk intensivbehandling?

- I forhold til det dere som personale bidro med

- I forhold til det som familie/pårørende bidro med

- I forhold til miljøet omkring pasienten (har dere opplevd ytringer fra pasienter om forhold ved miljøet/ omgivelsene som virket oppmuntrende på hans/hennes «livsgnist»?) (apparatene/senga/rommet, andre pasienter, lyder/støy/alarmer/musikk, farger, lukter ...)

- Faktorer i pasienten selv (spesielle ressurser, mestringsstrategier)

\section{Dataanalyse}

Intervjuene ble ordrett transkribert av første- og andreforfatter, avidentifisert og refleksjonsnotater knyttet til den transkriberte teksten ble notert. Tekstene ble analysert ved hjelp av Malteruds systematiske tekstkondensering (25). Vi tilstrebet en åpen tilnærming i første trinn hvor data ble nøye gjennomlest flere ganger for å få et helhetsbilde, ikke-relevant tekst ble utelatt. Videre jobbet første- og andreforfatter med identifisering av foreløpige tema og identifisering av meningsbærende enheter som ble fargekodet, diskutert og kodet. Deretter ble kategoriene diskutert i lys av relevant teori (OAS, GMR, indre styrke og vilje til overlevelse). Til slutt ble essensen sammenfattet og det fremstod fire hovedkategorier og ti sub-kategorier, som vist i tabell 2. Tabell 3 gir et eksempel på hvordan de ulike trinnene i analysen er gjennomført.

\section{Etiske vurderinger}

Skriftlig informasjon om studiens hensikt og informantenes rettigheter ble sendt til avdelingslederne som videreformidlet dette til de aktuelle informantene. Samtykkeskjema

Tabell 2: Kategorier og sub-kategorier

\begin{tabular}{llll}
\hline & \multicolumn{2}{c}{ Kategorier } & \\
\hline $\begin{array}{l}\text { A være vitne til } \\
\text { pasientens kamp }\end{array}$ & $\begin{array}{l}\text { Viljen til å komme hjem - } \\
\text { en sterk helsefremmende } \\
\text { kraft }\end{array}$ & $\begin{array}{l}\text { Pårørende - en viktig } \\
\text { helsefremmende ressurs }\end{array}$ & $\begin{array}{l}\text { Intensivsykepleieren - en } \\
\text { sentral helsefremmende } \\
\text { ressurs }\end{array}$ \\
\hline $\begin{array}{l}\text { Fysiske og psykiske } \\
\text { utfordringer }\end{array}$ & Lub-kategorier & Livsgnisten \\
Noen ønsker å gi opp & $\AA$ k komme hjem & Tilstedeværelsen & Handlinger \\
Viljen & & Pasientens stemme & Dilemmaene \\
\hline
\end{tabular}


Tabell 3: Analysestegene for en av kategoriene

\begin{tabular}{|c|c|c|c|}
\hline Meningsbærende enhet & Koding & Subkategori & Hovedkategori \\
\hline $\begin{array}{l}\text { Vi må få dem igjennom, det blir liksom det som } \\
\text { blir målet }\end{array}$ & $\begin{array}{l}\text { Overlevelse i } \\
\text { intensivavdeling }\end{array}$ & $\begin{array}{l}\text { Fysiske og psykiske } \\
\text { utfordringer }\end{array}$ & $\begin{array}{l}\text { A være vitne } \\
\text { til pasientens } \\
\text { kamp }\end{array}$ \\
\hline Apparatet har jo berget livet hans & & Noen ønsker å gi opp & \\
\hline $\begin{array}{l}\text { Må gjøre noe, selv om det ikke er noe å gjøre, } \\
\text { liker ikke å kjenne på den følelsen da, at en ikke } \\
\text { kan gjøre noe tror jeg }\end{array}$ & & Viljen & \\
\hline \multicolumn{4}{|l|}{$\begin{array}{l}\text { Jeg tror du bare kjenner at pasientens vilje er } \\
\text { der }\end{array}$} \\
\hline \multicolumn{4}{|l|}{$\begin{array}{l}\text { Det er så mange som tviler på å komme seg } \\
\text { igjennom, de tror at kroppen er i så dårlig } \\
\text { forfatning så er det liksom motløst alt sammen }\end{array}$} \\
\hline \multicolumn{4}{|l|}{$\begin{array}{l}\text { Den som virkelig ikke vil overleve - dør gjerne. } \\
\text { Det er nesten som de har bestemt seg. De sier } \\
\text { det, staver det, orker ikke mer, jeg vil dø }\end{array}$} \\
\hline \multicolumn{4}{|l|}{$\begin{array}{l}\text { Da er det en makaber følelse å være hos } \\
\text { pasienten. Jeg lurte på hva vi jobbet mot da. } \\
\text { For det gikk ikke noe særlig og jeg lurte virkelig } \\
\text { på hva det var vi drev med }\end{array}$} \\
\hline $\begin{array}{l}\text { Det var ikke så lett å være der inne i lange } \\
\text { perioder og motivere når hun ikke ville mer }\end{array}$ & & & \\
\hline
\end{tabular}

ble signert før fokusgruppediskusjonen startet. Ved starten av fokusgruppediskusjonene ble informasjon om studiens hensikt, informantenes rett til å kunne trekke seg når som helst uten forklaring samt ivaretagelse av anonymitet gjentatt. Studien er godkjent i REK (ref. nr. 2015/2311) som del av en større studie med fokus på langtidsintensivpasienters vilje til overlevelse. Denne studien inneholdt ingen persondata og var ikke meldepliktig ifølge NSD. Data ble lagret i henhold til interne retningslinjer for informasjonssikkerhet.

\section{Funn}

Begge kjønn var representert $\mathrm{i}$ utvalget. Ni informanter hadde videreutdanning $\mathrm{i}$ intensivsykepleie og alle hadde mer enn fem års erfaring fra intensivavdeling. Fokusgruppediskusjonene gav totalt trettini sider tekst med linjeavstand 1.0. Analysen gav fire hovedkategorier som dannet meningsstrukturen i intensivsykepleiernes opplevelser knyttet til langtids-intensivpasienters indre styrke og vilje til overlevelse: (1) å være vitne til pasientens kamp, (2) viljen til å komme hjem - en sterk helsefremmende kraft, (3) pårørende - en viktig helsefremmende ressurs og (4) intensivsykepleieren - en sentral helsefremmende ressurs.

\section{$\AA$ være vitne til pasientens kamp}

Intensivsykepleierne fortalte hva de gjorde for at pasientene skulle overleve særlig i den akutte fasen. De knyttet sine opplevelser til konkrete fortellinger relatert til den 
behandlingen de gav og hvordan medisinskteknisk utstyr støttet opp om pasientenes overlevelse. En sa:

«Apparatet har jo berget livet hans»

De kunne også fortelle ulike opplevelser knyttet til langtids-intensivpasientenes plager som smerte, delirium, redusert $\varsigma \varnothing \mathrm{vn}$, depresjon og angst. I pasientens akutte og kritiske fase fokuserte intensivsykepleierne på å gjøre ulike tiltak:

«Må gjøre noe, selv om det ikke er noe å gjøre, liker ikke å kjenne på den følelsen da, at en ikke kan gjøre noe tror jeg»

«Vi skal få dem igjennom, det blir liksom det som blir målet»

Det kan se ut som at kampen for pasientens overlevelse i større grad er knyttet til avansert intensivmedisinsk behandling og ikke til pasientens vilje i denne fasen av intensivoppholdet. Men etter den mest kritiske fasen, når pasientene ble mer bevisste og våkne, endrer dette seg. Intensivsykepleierne fortalte om pasientenes tvil og motløshet, særlig i møtet med sin fysisk svekkede kropp:

«Det er så mange som tviler på å komme seg igjennom, de tror at kroppen er i så dårlig forfatning så er det liksom motløst alt sammen»

I denne mer stabile fasen fortalte de om oppmerksomhet knyttet til pasientens indre styrke og vilje til overlevelse, viljen kunne fornemmes både på et abstrakt og et konkret plan:

«... jeg tror bare du kjenner at pasientens vilje er der»

«Den som virkelig ikke vil overleve - dør gjerne. Det er nesten som de har bestemt seg. De sier det, staver det, orker ikke mer, jeg vil dø ...»

Det kan være vanskelig og utfordrende å yte intensivsykepleie til pasienter som resignerer og hvor viljen og styrken blir mindre synlig. Intensivsykepleierne satte ord på dette: 
«Da er det en makaber følelse å være hos pasienten. Jeg lurte på hva vi jobbet mot da. For det gikk ikke noe særlig og jeg lurte virkelig på hva det var vi drev med»

$$
\left(I_{-} 3 c\right)
$$

«Det var ikke så lett å være der inne i lange perioder og motivere når hun ikke ville mer ...»

Intensivsykepleierne opplevde at mange intensivpasienter ikke forstod hvor nær døden de hadde vært. Å ha oppmerksomhet overfor pasientenes indre styrke og vilje til overlevelse er utfordrende, særlig i den akutte og kritiske fasen der fokuset i stor grad rettes mot avansert intensivbehandling og pasientene går inn og ut av bevissthet grunnet sedasjonsnivå og sykdomsforløp.

\section{Viljen til å komme hjem - en sterk helsefremmende kraft}

Intensivsykepleierne opplevde at pasienter som hadde vært aktive forut for intensivoppholdet hadde mer «giv», indre styrke og evnen til å se fremover. Samtidig erfarte de at pasienter med alvorlige kroniske sykdommer strevde mer, eksempelvis pasienter med kreft eller pasienter som var deprimerte. Sykepleierne fornemmet om pasienten orket mer eller ikke:

«Det spørs litt på forhistorien deres også, hva de har med seg inn i oppholdet her. Både fysisk og mentalt - ikke minst mentalt! En pasient som er depressiv fra før og blir utsatt for ei ulykke sånn helt uventet, takler det kanskje på en annen måte enn én som man ser på som en ressurssterk og aktiv person»

I samtlige fokusgrupper kom det frem at å skissere fremtiden for pasienten var viktig: «A komme hjem» var et forløsende ord i samtalene med intensivpasientene. Selv om målet å komme hjem syntes langt frem, opplevde intensivsykepleierne at dette fokuset forløste pasientenes indre styrke og vilje til overlevelse:

«Viljen til å komme hjem er kanskje et uttrykk for viljen til overlevelse. Det ser jeg er kjempeviktig for noen. De skjønner kanskje innerst inne at det ikke er så enkelt, men det blir liksom målet»

Pasientenes levde liv og å ha noe konkret å se frem til og jobbe mot, var viktig for pasientenes indre styrke og vilje til overlevelse. 


\section{Pårørende - en viktig helsefremmende ressurs}

Intensivsykepleierne oppfattet familie eller andre nære kjente som viktige ressurser: Disse representerte en positiv kraft i pasientens intensivtilværelse. Derfor vektla intensivsykepleierne «rimelig fri flyt» i pårørendes tilstedeværelse. Samtidig var de opptatt av å ikke slite ut pasienten i forbindelse med bes $\varnothing \mathrm{k}$. Derfor var det vesentlig å sette grenser for familien både for å ivareta pasienten, pårørende og sin egen arbeidssituasjon:

«Noen pårørende vet ikke hva de skal gjøre, de blir lett satt på sidelinja. Kanskje har de lyst til å være der inne hele tiden, men det er jo ikke bra for da sliter de seg totalt ut! Og pasientene blir også slitne, for de trenger hvile og jeg skal rekke å gjøre prosedyrene, gå igjennom dagen ...»

Intensivsykepleierne opplevde at pårørende bidro med viktig informasjon om pasienten som person, dekunnevære pasientens stemme. Dettehjalp personaletikommunikasjonen og samhandlingen med pasienten, og bidro til en mer personlig tilnærming. Pårørendes tilstedeværelse fremmet pasientens indre styrke og vilje til overlevelse. A kunne snakke med pasienten om annet enn «vaktprat», for eksempel se på bilder av barnebarn eller hunden, gav et godt utgangspunkt for en mer personlig og hyggelig samtale:

«En pasient hadde hund. Jeg husker familien tok den med hit til avdelingen. Det tror jeg hjalp ham et stort skritt videre i prosessen»

Pårørendes betydning anses som viktig, men intensivsykepleierne må balansere pårørendes tilstedeværelse. Nær familie kan være pasientens stemme og bidra til en forankring til livet utenfor intensivavdelingen og bringe inn aspekter i pasientens liv som kan fremme den indre styrken og viljen til overlevelse.

\section{Intensivsykepleieren - en sentral helsefremmende ressurs}

Intensivsykepleierne brukte ofte begrepet «å pushe» og «å strekke strikken» når de snakket om sin rolle. De erfarne intensivsykepleierne turte å utfordre pasientene, og erfarte at pasientene klarte mer enn de selv var klar over:

«Vi må tenke positivt og si at det går fremover: Selv om det er strevsomt nå, vil det bli bedre!»

På den ene siden trenger intensivsykepleierne kjennskap til pasienten for å tilpasse sykepleien, på den andre siden er det essensielt å bli kjent med pasienten som person for å kunne fremme pasientens indre styrke og vilje til overlevelse: 
«Jeg tenker at for å få folk til å få en gnist, et ønske om å leve videre, må vi ta tak i den personen som det egentlig er, ikke bare den syke som ligger i sengen»

(Id_2a)

En pasient $\varnothing$ nsket et glass vin «... og jeg tenkte, hvorfor ikke?» (Id_3d). Flere informanter fortalte at de tilbyr radio eller TV for å normalisere situasjonen for pasienten og dermed bidra med handlinger som kunne fremme pasientens indre styrke. Kontakt med pasienten og det å skape gode relasjoner ble fremhevet:

«Datteren min sa en gang: Ah, trenger du å sminke deg før du skal på jobb? Og jeg sa ja, for i dag er det nesten bare meg pasienten kommer til å se»

$(I d-3 a)$

Gjennom ulike handlinger viser intensivsykepleierne at de bidrar positivt og dermed fremmer pasientenes vilje til overlevelse på en profesjonell måte. Men intensivsykepleierne kunne også fortelle om situasjoner der deopplevdeå ståi et dilemma. Eksempelvis opplevde intensivsykepleierne bekymring for hva pasientene oppfattet da behandlingsteamet vurderte å avslutte behandling. Kunne dette svekke pasientens indre styrke og vilje til overlevelse? En intensivsykepleier uttrykte:

«Jeg vil jo alle vel. Samme om de skal dø eller leve videre så $\varnothing$ nsker en jo grunnleggende sykepleie som dekker alle pasientens behov. Ønsker å være god i hendene mine. Dette er et håndverk, jeg liker ikke å tenke på at jeg kanskje har et annet grep, et annet håndlag hvis jeg ikke har troen på at dette skal gå bra ...»

Intensivsykepleierne opplevde at deres tilstedeværelse kunne ha betydning også for pasientens indre styrke og vilje til overlevelse.

\section{Diskusjon}

Denne studien utforsker hvilke opplevelser intensivsykepleiere har med langtidsintensivpasienters indre styrke og vilje til overlevelse.

\section{Helsefremming i den akutte fasen av intensivoppholdet}

Resultatet indikerer at desto mer akutt og kritisk pasientens situasjon er, jo mindre er intensivsykepleieres oppmerksomhet rettet mot pasientens indre styrke og vilje til overlevelse. De siste årsrapportene fra Norsk intensivregister viser at de fleste pasienter overlever grunnet avansert behandling, medisinskteknisk utstyr og spesialutdannet personell $(1,2)$. Dermed er det ikke uventet at intensivsykepleierne i denne fasen $\mathrm{i}$ 
mindre grad er oppmerksomme overfor pasientens vilje til overlevelse. Denne studien viser at deres forståelse var at pasientens vilje og indre styrke blir aktualisert først når pasienten er mer våken. De uttrykte mindre oppmerksomhet overfor fenomenet når pasientene var sedert og under respiratorbehandling. A sette klare skillelinjer mellom «våken» og sedert» kan være utfordrende. Som en konsekvens av intensivbehandlingen vil en intensivpasient befinne seg på ulike steder mellom disse to ytterpunktene. Alexandersen og kolleger fant at langtids-intensivpasienter som er mer eller mindre bevisst, kan oppleve indre styrke og en overbevisning om å overleve på tross av alvorlige skader og sykdom, selv om deres mål kan fremstå urealistiske (17). Både positive og fryktinngytende drømmer og fantasier i den akutte fasen er beskrevet av mange intensivpasienter. Noen skildrer et vendepunkt i løpet av drømmen hvor de forstår at de skal vende tilbake til livet: Dette kan være uttrykk for pasientens indre styrke og livskraft (17). A anerkjenne pasientens opplevelser som uttrykk for følelser og reaksjoner på ekstreme påkjenninger kan øke pasientens opplevelse av å bli ivaretatt som et helt menneske og ikke bare en kropp som skal repareres. Haugdahl og kolleger fremhever behovet for et skifte fra en ensidig teknisk-instrumentell sykepleie over mot å integrere det tekniske $\mathrm{i}$ et helsefremmende perspektiv med vekting av pasientens forståelse samt mer involvering av både pasient og pårørende (27). I 2017 ble det helsefremmende perspektivet fremhevet i intensivsykepleierens funksjons- og ansvarsbeskrivelse (7), dermed kan oppmerksomheten mot et helsefremmende perspektiv være større i dag enn da våre data ble innsamlet. Anerkjennelse av pasientens opplevelser, rasjonelle eller ikke, vil virke helsefremmende i en ellers krevende situasjon. Å vektlegge pasientenes vilje og indre styrke som helsefremmende ressurser også i den akutte fasen synes viktig for å fremme langtids-intensivpasientenes overlevelse, indre styrke og velvære $(5,17,21)$.

\section{Salutogen intensivsykepleie}

Å være langtidspasient i intensivavdelingen er krevende $(4,5,28)$. I denne situasjonen kan pasienten ha varierende mulighet for å ta i bruk egne ressurser. Egerod og kolleger (5) samt Alexandersen og kolleger viser at langtids-intensivpasientens indre styrke og vilje til overlevelse utfordres sterkt $(5,17)$. Flere studier viser at noen langtids-intensivpasienter demonstrerer en eksepsjonell indre styrke $(14,17)$ og vilje til å leve $(20,29)$. Lignende funn er gjort i andre pasientpopulasjoner, for eksempel viser studier av Jenkinson \& Cantrell (30) og Dingly \& Roux (31) at kronisk syke kvinners indre styrke fungerer som en helsefremmende ressurs.

Vår studie viser at intensivsykepleierne var opptatt av å se og anerkjenne pasienten som en unik person. De fortalte om handlinger de gjorde når pasientens tilstand ble mer stabil og pasienten var mindre sedert. Å legge til rette for bes $\varnothing \mathrm{k}$ av hunden, gi en smak av vin eller skape normalitet for pasienten ved å tilby radio eller TV, kan forstås som å styrke pasientens livsmot ved et «friminutt» fra lidelsen, og slik frigi energi til å bearbeide plagsomme opplevelser og erfaringer (13). En slik «normalisering» er en måte 
å fremme pasientens indre styrke og representerer derved helsefremmende strategier. Ved å anerkjenne hver pasient som en unik person og bidra til at intensivpasienten mestrer sine plager, kan intensivsykepleieren være en sentral ressurs for pasienten (9). Dette støttes av Alpers og kolleger (20), som understreker at å se intensivpasientene som unike personer er viktig for pasientenes opplevelse av indre styrke. Intensivsykepleierne i denne studien fasiliterte pasientenes styrke gjennom å skissere en fremtid der pasienten var kommet hjem. Å minne pasientene på hva de kan se frem til var også et funn i Wåhlins studie (11).

I tråd med tidligere forskning erfarte intensivsykepleierne at familiens tilstedeværelse vekker til liv pasientenes indre styrke og vilje til overlevelse (27). Ifølge Haugdahl og hennes kolleger var to ressurser særlig betydningsfulle for langtids-intensivpasientens gjennombrudd mot overlevelse: 1) pårørendes tilstedeværelse som trekker pasienten til et eksistensielt «her-værende», og 2) pasientens indre styrke og vilje som fremmer helseprosessene mot overlevelse (21). Samtidig eksisterer et dilemma mellom pårørendes hyppige tilstedeværelse og intensivsykepleiernes planlagte arbeidsoppgaver: nytten av familiens tilstedeværelse må ses opp mot ulempene for intensivsykepleiernes arbeidssituasjon. I tråd med tidligere studier $(5,21,32,33)$ prioriterte intensivsykepleierne også i denne studien familiens tilstedeværelse fordi den fremstod som svært viktig for intensivpasientens helbredende prosesser.

Intensivsykepleierne i vår studie demonstrerte i mindre grad et faglig begrepsapparat som er dekkende for fenomenene pasientens indre styrke og vilje til overlevelse. De fortalte mye om hvordan de «pushet» og «strekte strikken» med tanke på pasientenes kamp for overlevelse, men mindre om pasientens egen vilje, livsmot og indre styrke. Kunnskap om OAS (opplevelse av sammenheng) kan hjelpe helsepersonell til å bli oppmerksom på hvordan pasienten begriper, håndterer og finner mening i denne krevende livssituasjonen (12). Figur 1 viser den teoretiske sammenhengen mellom begrepene som inngår i denne studien, basert på Antonovskys helse-kontinuum hvor ethvert individ til enhver tid befinner seg et sted mellom dis-ease $(\mathrm{H}-)$ og ease $(\mathrm{H}+)$. Ø $\varnothing t$ oppmerksomhet overfor intensivpasientens OAS, det vil si begripelighet, meningsfullhet og håndter-

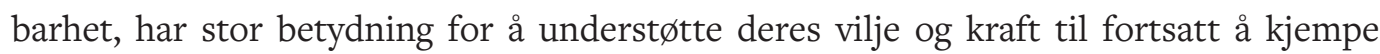
$(29,34)$. Begrepet livsmot inngår nå $\mathrm{i}$ intensivsykepleiernes funksjons- og ansvarsbeskrivelse (7). Livsmot er nært relatert til de salutogene fenomenene indre styrke og vilje til overlevelse (13-15), det kan derfor være interessant å løfte frem også denne siden ved intensivsykepleien. Som vist i figur 1 har intensivpasienter med alvorlig sykdom/ skade fortsatt en grad av helse, og ved økt bevisst oppmerksomhet mot de salutogene ressursene vil intensivsykepleierne i større grad kunne bidra til å bevege pasientene mot helsen (ease) (figur 1).

\section{Studiens styrker og begrensninger}

Totalt deltok ti informanter i tre ulike fokusgruppediskusjoner. For å tilstrebe god erfaringsbredde i utvalget, representerte informantene tre ulike sykehus med ulikt 
pasientgrunnlag. Informantene var erfarne intensivsykepleiere og representerer kliniske eksperter relatert til studiens kunnskapsmessige siktemål. Det relativt lave antallet informanter er en svakhet ved studien. Flere informanter og flere fokusgruppediskusjoner ville kunne bidra til større bredde i data med ulike tema og nyanser som ikke fremkommer i denne studien. Til tross for få informanter, ble det ikke gjennomført flere fokusgruppediskusjoner av ressurshensyn. Denne studien bygger på norske bemanningsforhold, noe som begrenser overføringsverdien av våre funn internasjonalt (35). Forskernes forforståelse er basert i lang klinisk erfaring fra intensivsykepleie samt undervisningserfaring ved videreutdanning i intensivsykepleie og generell sykepleie. Dette styrker studiens validitet. Samtidig kan dette ha medført færre utforskende og oppfølgende spørsmål under fokusgruppediskusjonene, da forfatterne implisitt forstod hva informantene mente og dermed ikke bidro til ytterligere utdypninger som kunne gitt dypere forståelse av fenomenet. Intervjuguiden representerer forskernes forforståelse; den var åpent utformet med tanke på å holde forforståelsen i «parentes» (26). Sisteforfatter har omfattende publikasjoner innen helsefremming basert i den salutogene helseforståelsen, men har ikke klinisk erfaring fra intensivavdelinger. Sisteforfatter representerer dermed en åpen tilnærming til tolkningen av data. Kombinasjonen av disse perspektivene er en styrke ved denne studien.

Pasienter som ikke overlever, er ikke fokusert i denne studien. Den salutogene helseforståelsen innebærer at individet alltid har en grad av helse frem til døden inntrer. A fremme pasienters helse er en sentral del av alt helsearbeid, også i intensivavdelingen, uavhengig av om pasienten overlever eller ikke. Ved hjelp av dybdeintervju med erfarne og mindre erfarne intensivsykepleiere, tidligere intensivpasienter og deres pårørende kan kunnskap om hvordan sykepleiere kan fremme langtids-intensivpasienters indre styrke og vilje til overlevelse utvikles videre.

\section{Konklusjon}

Intensivsykepleiere synes mindre oppmerksomme overfor langtids-intensivpasienters indre styrke og vilje til overlevelse i den akutte og kritiske fasen: oppmerksomhet overfor dette aktualiseres i hovedsak når pasienten er mer stabil og mindre sedert. Helsefremmende tiltak involverer å normalisere pasientens hverdag, eller ved å gjøre «det lille ekstra» som for eksempel tilby et glass vin, samt å anerkjenne og ivareta pårørende som en viktig salutogen ressurs. Studien bidrar til kunnskap om hvordan intensivsykepleiere opplever langtids-intensivpasienters indre styrke og vilje til overlevelse. Selv om intensivsykepleierne i denne studien i mindre grad er bevisst begrepene innen helsefremmende sykepleie, utfører de handlinger som bidrar til å fremme pasientens GMR. Kunnskap om betydningen av langtids-intensivpasienters indre styrke og viljestyrke kan bidra til mestring, mindre traumatiske opplevelser og dermed $\varnothing \mathrm{kt}$ velvære for pasientene. Dette er fundamentalt når pasientene skal fortsette sine liv hjemme etter intensivoppholdet. Kunnskapen om salutogen intensivsykepleie bør videreutvikles og inkluderes i utdanning av intensivsykepleiere og deres kliniske praksis. 


\section{Kliniske implikasjoner}

Videreutvikling av intensivsykepleie, både teoretisk og klinisk, i en mer helsefremmende retning synes fundamentalt. Intensivsykepleie skal forankres i kunnskap om både patogenese og salutogenese, som sammen danner basis for en integrert holistisk helseforståelse og salutogen intensivsykepleie $(12,36)$. Intensivsykepleiere bør ifølge Price ivareta pasientens kroppslige funksjoner, og samtidig fasilitere pasientens OAS, indre styrke og vilje, og dermed fremme pasientens mestring, helse og overlevelse (37). Slik kan intensivsykepleiere skape et best mulig utgangspunkt for pasientens mestring hjemme etter sykehusoppholdet.

Utdanning av intensivsykepleiere $b \varnothing r$ if $\varnothing$ lge Haugan og Rannestad baseres i en mer tydelig og eksplisitt integrasjon av patogenesen og salutogenesen (38). Parallelt med kunnskap om kompleks og avansert intensivmedisinsk behandling, bør intensivsykepleierne inneha kunnskap om hvordan pasientens opplevelse av begripelighet, håndterbarhet og meningsfullhet samt indre styrke og vilje til overlevelse kan fremmes under langtids intensivbehandling (27). Intensivsykepleiere trenger kunnskap om helsefremming, salutogene ressurser og pasientens generelle motstandsressurser (9). Intensivsykepleiernes funksjons- og ansvarsbeskrivelse, helsefremmende litteratur og Haugdahl og kollegers utvikling av en tentativ teori om salutogen intensivsykepleie er aktuelle bidrag fremover (27).

\section{Takksigelser}

Takk til alle involverte parter som har bidratt til å gjøre denne studien mulig. Spesielt takk til avdelingslederne som hjalp oss med rekruttering av informanter og ikke minst til informantene som villige til å dele sine erfaringer og har brukt av sin dyrebare tid til dette.

\section{Referanser}

1. Buanes EA, Kvåle R, Baratt-Due A. Norsk intensivregister Årsrapport for 2019 med plan for forbetringstiltak Versjon 1.1. 2020 Lastet ned 15.02.2021 fra https://helse-bergen.no/norskintensivregister-nir/arsrapportar

2. Buanes EA, Kvåle R, Baratt-Due A. Norsk intensivregister Årsrapport for 2018 med plan for forbetringstiltak Versjon 1.1. 2019 Lastet ned 15.02.2021 fra https://helse-bergen.no/norskintensivregister-nir/arsrapportar

3. Berntzen H, Bjørk IT, Wøien H. «Having the compass-drawing the map»: Exploring nurses' management of pain and other discomforts during use of analgosedation in intensive care. Nurs Open. 2018;6(2):453-62. https://doi.org/10.1002/nop2.227

4. Hashem MD, Nallagangula A, Nalamalapu S, Nunna K, Nausran U, Robinson KA, et al. Patient outcomes after critical illness: A systematic review of qualitative studies following hospital discharge. Crit Care. 2016;20(1). https://doi.org/10.1186/s13054-016-1516-x

5. $\quad$ Egerod I, Bergbom I, Lindahl B, Henricson M, Granberg-Axell A, Storli SL. The patient experience of intensive care: A meta-synthesis of Nordic studies. Int J Nurs Stud. 2015;52(8):1354-61. https://doi.org/10.1016/j.ijnurstu.2015.04.017 
6. Merbitz NH, Westie K, Dammeyer JA, Butt L, Schneider J. After critical care: Challenges in the transition to inpatient rehabilitation. Rehabil Psychol. 2016;61(2):186-200. https://doi.org/10.1037/ repoo00072

7. Norsk sykepleieforbunds landsgruppe av intensivsykepleiere NSFLIS. Funksjons- og ansvarsbeskrivelse for intensivsykepleier 2017 Lastet ned 15.02.2021 fra https://www.nsf.no/sites/ default/files/inline-images/czwgg4sqZCCRzfiNDM56nSWsxIgGCkwVuoUeofcXZ6NYPysIQb.pdf

8. Rannestad T, Haugan G. Helsefremming i spesialisthelsetjenesten. I: Haugan G, Rannestad T, red. Helsefremming i spesialisthelsetjenesten. Oslo: Cappelen Damm Akademisk; 2016. s. 19-32.

9. Antonovsky A. The salutogenic model as a theory to guide health promotion. Health Promot Int. 1996;11(1):11-8. https://doi.org/10.1093/heapro/11.1.11

10. Antonovsky A, Sjøbu A. Helsens mysterium: den salutogene modellen. Oslo: Gyldendal akademisk; 2012.

11. Wåhlin ICRNP, Samuelsson PMDP, Ågren SCP. What do patients rate as most important when cared for in the ICU and how often is this met? - An empowerment questionnaire survey. J Crit Care. 2017;40:83-90. https://doi.org/10.1016/j.jcrc.2017.03.004

12. Drageset S, Ellingsen S, Haugan G. Å mestre livet ved alvorlig sykdom. Nordisk sygeplejeforskning. 2017(4):294-302. https://doi.org/10.18261/issn.1892-2686-2017-04-03

13. Martinsen K. Fra Marx til Løgstrup: om etikk og sanselighet i sykepleien. 2. utg. Oslo: Universitetsforl.; 2003.

14. Smith CS, Dingley C, Roux G. Inner strength—state of the science. Can J Nurs Res. 2019;51(1):38-48. https://doi.org/10.1177/0844562118790714

15. Henden E. What is self-control? Philosophical psychology. 2008;21(1):69-90. https://doi.org/10.1080/ 09515080701874092

16. Karp T, Lægreid LM, Moe HT. The power of willpower: Strategies to unleash willpower resources. Scandinavian Journal of Organizational Psychology. 2014;6.

17. Alexandersen I, Stjern B, Eide R, Haugdahl HS, Engan Paulsby T, Borgen Lund S, et al. «Never in my mind to give up!» A qualitative study of long-term intensive care patients' inner strength and willpower-Promoting and challenging aspects. J Clin Nurs. 2019;28(21-22):3991-4003. https://doi. org/10.1111/jocn.14980

18. Alexandersen I, Haugdahl HS, Paulsby TE, Lund SB, Stjern B, Eide R, et al. A qualitative study of long-term ICU patients' inner strength and willpower: Family and health professionals as a healthpromoting resource. J Clin Nurs. 2021;30(1-2):161-73. https://doi.org/10.1111/jocn.15532

19. Marra A, Ely EW, Pandharipande PP, Patel MB. The ABCDEF bundle in critical care. Crit Care Clin. 2017;33(2):225-43. https://doi.org/10.1016/j.ccc.2016.12.005

20. Alpers L-M, Helseth S, Bergbom I. Experiences of inner strength in critically ill patients - A hermeneutical approach. Intensive Crit Care Nurs. 2012;28(3):150-8. https://doi.org/10.1016/j.iccn. 2011.10.004

21. Haugdahl HS, Eide R, Alexandersen I, Paulsby TE, Stjern B, Lund SB, et al. From breaking point to breakthrough during the ICU stay: A qualitative study of family members' experiences of long-term intensive care patients' pathways towards survival. J Clin Nurs. 2018;27(19-20):3630-40. https://doi. org/10.1111/jocn.14523

22. Ning J, Cope V. Open visiting in adult intensive care units - A structured literature review. Intensive Crit Care Nurs. 2020;56. https://doi.org/10.1016/j.iccn.2019.102763

23. Malterud K. Kvalitative forskningsmetoder for medisin og helsefag. 4. utg. Oslo: Universitetsforl.; 2017.

24. Halkier B. Focus groups as social enactments: Integrating interaction and content in the analysis of focus group data. Qualitative Research. 2010;10(1):71-89. https://doi.org/10.1177/1468794109348683 
25. Malterud K. Fokusgrupper som forskningsmetode for medisin og helsefag. Oslo: Universitetsforl.; 2012.

26. Malterud K. Qualitative research: Standards, challenges, and guidelines. Lancet. 2001;358(9280): 483-8. https://doi.org/10.1016/So140-6736(01)05627-6

27. Haugdahl HS, Alexandersen I, Haugan G. Family-centered long-term intensive care - A tentative health promoting theory. I: Haugan G, Eriksson M, red. Health promotion in health care - Vital salutogenic theories and research. Under utgivelse: Springer Scientific Publisher; 2021.

28. Barr J, Fraser GL, Puntillo K, Ely EW, Gélinas C, Dasta JF, et al. Clinical practice guidelines for the management of pain, agitation, and delirium in adult patients in the intensive care unit. Crit Care Med. 2013;41(1):263-306. https://doi.org/10.1097/CCM.obo13e3182783b72

29. Engström $\AA$, Nyström N, Sundelin G, Rattray J. People's experiences of being mechanically ventilated in an ICU: A qualitative study. Intensive Crit Care Nurs. 2013;29(2):88-95. https://doi.org/10.1016/ j.iccn.2012.07.003

30. Jenkinson A, Cantrell MA. Inner strength in women with chronic illness. Chronic Illn. 2017;13(2): 100-16. https://doi.org/10.1177/1742395316664961

31. Dingley C, Roux G. The role of inner strength in quality of life and self-management in women survivors of cancer. Res Nurs Health. 2014;37(1):32-41. https://doi.org/10.1002/nur.21579

32. Engström $\AA$, Söderberg S. Receiving power through confirmation: The meaning of close relatives for people who have been critically ill. J Adv Nurs. 2007;59(6):569-76. https://doi.org/10.1111/j.1365-2648. 2007.04336.x

33. Wassenaar A, Schouten J, Schoonhoven L. Factors promoting intensive care patients' perception of feeling safe: A systematic review. Int J Nurs Stud. 2014;51(2):261-73. https://doi.org/10.1016/ j.ijnurstu.2013.07.003

34. Karlsson V, Bergbom I, Forsberg A. The lived experiences of adult intensive care patients who were conscious during mechanical ventilation: A phenomenological-hermeneutic study. Intensive Crit Care Nurs. 2012;28(1):6-15. https://doi.org/10.1016/j.iccn.2011.11.002

35. Stafseth SK, Solms D, Bredal IS. The characterisation of workloads and nursing staff allocation in intensive care units: A descriptive study using the Nursing Activities Score for the first time in Norway. Intensive Crit Care Nurs. 2011;27(5):290-4. https://doi.org/10.1016/j.iccn. 2011.07 .003

36. Haugan G, Eriksson M. Health promotion in health care - Vital salutogenic theories and research. I: Haugan G, Eriksson M, red. Health promotion in health care- Vital salutogenic theories and research. Under utgivelse: Springer Scientific Publisher; 2021.

37. Price AM. Intensive care nurses' experiences of assessing and dealing with patients' psychological needs. Nurs Crit Care. 2004;9(3):134-42. https://doi.org/10.1111/j.1362-1017.2004.00055.x

38. Haugan G, Rannestad T. Helsefremmende helsearbeid - patogenese og salutogenese. I: Haugan G, Rannestad T, red. Helsefremming i spesialisthelsetjenesten. Oslo: Cappelen Damm Akademisk; 2016. S. $34-55$. 